\title{
Assessment of aerosol's mass concentrations from measured linear particle depolarization ratio (vertically resolved) and simulations
}

\author{
A. Nemuc, J. Vasilescu, C. Talianu, L. Belegante, and D. Nicolae \\ National Institute of R\&D for Optoelectronics, Magurele, Ilfov, Romania \\ Correspondence to: D. Nicolae (nnicol@inoe.ro) \\ Received: 30 April 2013 - Published in Atmos. Meas. Tech. Discuss.: 27 June 2013 \\ Revised: 7 October 2013 - Accepted: 26 October 2013 - Published: 27 November 2013
}

\begin{abstract}
Multi-wavelength depolarization Raman lidar measurements from Magurele, Romania are used in this study along with simulated mass-extinction efficiencies to calculate the mass concentration profiles of different atmospheric components, due to their different depolarization contribution to the $532 \mathrm{~nm}$ backscatter coefficient. Linear particle depolarization ratio ( $\left.\delta^{\text {part }}\right)$ was computed using the relative amplification factor and the system-dependent molecular depolarization. The low depolarizing component was considered as urban/smoke, with a mean $\delta^{\text {part }}$ of $3 \%$, while for the high depolarizing component (mineral dust) a mean $\delta^{\text {part }}$ of $35 \%$ was assumed.

For this study 11 months of lidar measurements were analysed. Two study cases are presented in details: one for a typical Saharan dust aerosol intrusion, 10 June 2012 and one for 12 July 2012 when a lofted layer consisting of biomass burning smoke extended from 3 to $4.5 \mathrm{~km}$ height.

Optical Properties of Aerosols and Clouds software package (OPAC) classification and conversion factors were used to calculate mass concentrations. We found that calibrated depolarization measurements are critical in distinguishing between smoke-reach aerosol during the winter and dustreach aerosol during the summer, as well as between elevated aerosol layers having different origins. Good agreement was found between lidar retrievals and DREAM- Dust REgional Atmospheric Model forecasts in cases of Saharan dust. Our method was also compared against LIRIC (The Lidar/Radiometer Inversion Code) and very small differences were observed.
\end{abstract}

\section{Introduction}

In recent years, there has been a substantial increase in studying the influence of aerosols on the climate through both direct and indirect radiative effects (Lesins et al., 2002). The major natural aerosol components are sea salt, dust, natural sulphates, volcanic aerosols, and those generated by natural forest fires. Aerosols can have an infinite variety of shapes, composition, sizes and other properties that influence their optical characteristics and thus the radiative impact (Satheesh and Krishna, 2005).

Active remote-sensing techniques such as Lidar have been proved to provide real-time measurements of the aerosol profile (e.g. Heese and Wiegner, 2008; Ansmann et al., 2012). The principle is based on the detection of the emerging light which results from the interactions of the laser beam with the atmospheric components. The backscattered light contains information on the properties of the atmospheric components. Methods to retrieve the optical properties of aerosols from elastic backscatter, Raman and multi-wavelength lidars are largely described in the literature (Fernald et al., 1972; Klett, 1981; Kovalev and Eichinger, 2004).

An important advance in the remote sensing of aerosols is the development of continental-scale lidar networks, which provide quality assured optical profiles on a large temporal and spatial scale. EARLINET, the European Aerosol Research Lidar Network (Pappalardo et al., 2013) data are relevant for climatology, but also for special events: Saharan dust outbreaks (Müller et al., 2003; Preißler et al., 2011), forest-fire smoke plumes transported over large areas, photochemical smog and volcano eruptions (e.g. Papayannis et al., 2008; Amiridis et al., 2009, 2011; Ansmann et al., 2009). The multi-wavelength Raman lidar systems equipped with 
depolarization channel (the "so called" $3+2+\delta$ lidar systems) are nowadays the most advanced systems providing extended datasest of aerosol optical parameters for aerosol characterisation (Mona et al., 2012), using complex retrieval algorithms (Chaikovski et al., 2004; Pappalardo et al., 2004; Mamouri et al., 2012).

Many studies in the recent literature have been especially dedicated to the volcanic eruptions (e.g. Hervo et al., 2012; Hogan et al., 2013). Gasteiger et al. (2011), showing that the consideration of the non-sphericity of the ash particles is necessary because the relevant optical properties are shapedependent, particularly in case of lidar measurements. Moreover, particle volume tends to extinct more light with increasing non-sphericity. Thus, the assumption of spherical particles in a retrieval would lead to an overestimation of the volume and the mass of ash particles, or other kind of non-spherical particles. Several techniques have also been developed to separate the fine (biomass burning smoke, urban haze) and coarse (sea salt, desert dust) aerosol profiles (Tesche et al., 2009a, b, and references within), with the scope of retrieving the mass concentration. Some of these methods also separate the coarse mode in coarse spherical and coarse non-spherical particles.

The Lidar/Radiometer Inversion Code (LIRIC) combines the multi-wavelength lidar technique with sun-sky photometry and retrieves vertical profiles of particle optical and microphysical properties, along with mass concentrations, separately for fine-mode and coarse-mode particles (Dubovik et al., 2012). LIRIC uses photometer-derived volume-specific backscatter and extinction coefficients for spherical as well as non-spherical particles for both fine and coarse modes (Wagner et al., 2013), based on the assumption that ensemble of randomly oriented spheroids mimics the optical properties of irregular shape particles.

The depolarization products (Sassen, 2005; Ansmann et al., 2012) obtained from lidar proved to distinguish between spherical (low depolarization ratios) and non-spherical particles (high depolarization ratios). Veselovskii et al. (2010) used a modified data inversion algorithm (Veselovskii et al., 2002) for the retrieval of dust microphysical parameters from a set of lidar optical data (backscatter coefficients at 3 wavelengths, extinction coefficients at 2 wavelengths) including the depolarization ratio at one wavelength. The data set described a mixed Saharan dust/continental haze plume observed over Southwest Germany in summer 2007 and showed the utility of depolarization ratio in the retrievals. Heese and Wiegner (2008) showed the importance of linear particle depolarization ratio $\left(\delta^{\text {part }}\right)$ measurements for discriminating between dust ( $\delta^{\text {part }}$ about $25 \%$ ) and biomass burning aerosols $\left(\delta^{\text {part }}\right.$ below $\left.10 \%\right)$.

Several studies (e.g. Shin et al., 2013; Ansmann et al., 2003; Freudenthaler et al., 2009; Sassen et al., 2007) presented results related to a single-type of aerosol, i.e. mineral dust. Nevertheless, the atmosphere is generally composed of a mixture of different aerosol types, having completely different scattering and absorption properties (Gobbi, 1998). Sugimoto and Lee (2006) developed a simple two-component theory considering two types of aerosol (dust and spherical aerosols) and applied to the observed data. Ansmann et al. (2012) presented an extended review of recent measurements of mass extinction efficiencies (defined as the ratio of aerosol mass concentration to extinction coefficient) for Saharan and volcanic dust. Such specific extinction coefficients are required to convert measured particle optical properties into mass concentration information.

Tesche et al. (2009a) used the $532 \mathrm{~nm}$ particle depolarization ratio to quantitatively separate dust and non-dust contributions to the $532 \mathrm{~nm}$ backscatter coefficient. They used as inputs the measured aerosol backscatter coefficient and linear particle depolarization, as well as assumed mean values of linear particle depolarization for the pure dust and pure smoke. Their method can be applied for any mixture of low and high-depolarizing aerosols, with a priori knowledge of the mean optical characteristics of the two assumed aerosol components. The method requires high accuracy input data (i.e. calibrated backscatter and depolarization), as well as complementary information on the type of components.

Our approach is similar but further we used modelled data (mass extinction efficiencies from OPAC) to calculate mass concentration profiles. The principle is presented in Sect. 2 along with the instrument. Mass concentration profiles for two cases (long-range transported Saharan dust and Biomass Burning Aerosol) are presented and discussed in Sect. 3. Typical profiles for cold and hot season are also shown. Discussions and conclusions are at the end of the paper.

\section{Instruments and methodology}

\subsection{Instruments}

\subsubsection{Multi-wavelength depolarization Raman lidar}

For this study we used the multi-wavelength depolarization Raman lidar measuring at Magurele, near Bucharest, Romania $\left(26.029^{\circ} \mathrm{E}, 44.048^{\circ} \mathrm{N}, 93 \mathrm{~m}\right.$ above sea level) since 2007 as part of EARLINET. The instrument employs an NdYAG laser emitting at 1064, 532 and $355 \mathrm{~nm}$, with a total $330 \mathrm{~mJ} / 9 \mathrm{~ns}$ laser pulse. The $400 \mathrm{~mm}$ diameter $/ 4047 \mathrm{~mm}$ focal length Cassegrain telescope collects the backscattered light and distributes it to the optical chain. The dynamic range is limited in the lower part by the overlap of the laser beam and the field-of-view of the telescope, but at the same time it is limited in the higher part by the level of the signalto-noise ratio. The size of the primary optics (in this case the diameter of the main mirror of the telescope) is an important factor in determining the effectiveness of a lidar system, which decreases with range. A larger primary optics collect a larger fraction of the scattered light and thus increase the signal measured by the lidar, but also increases 
the background radiation and thus the noise. To minimise the noise, the laser beam has a low divergence $1.085 \mathrm{mrad}$ at $1064 \mathrm{~nm}, 1.124 \mathrm{mrad}$ at $532 \mathrm{~nm}, 1.57 \mathrm{mrad}$ at $355 \mathrm{~nm}$ ), before the beam expansion and $0.22 \mathrm{mrad}$ at $1064 \mathrm{~nm}$ and $532 \mathrm{~nm}, 0.39 \mathrm{mrad}$ at $355 \mathrm{~nm}$ after it. The telescope's fieldof-view is optimized at $1.7 \mathrm{mrad}$. This is a good compromise in order to obtain a proper dynamic range, which includes the higher layers of the PBL $(>0.8 \mathrm{Km})$ and the whole troposphere $(<15 \mathrm{Km})$.

After collection by the primary optics, the light is processed before it is directed to the detector system. This processing is based on wavelength, polarization and range, in order to produce a record of the measured intensity as a function of altitude, on various channels. The system has 12 channels (Fig. 1), recording the backscattered light at 1064, $532 \mathrm{p}$ (parallel polarized), $532 \mathrm{~s}$ (cross polarized), 355, 607, 387 and $408 \mathrm{~nm}$, using analogue and photon counting detection for almost all channels (except $1064 \mathrm{~nm}$ - only analogue, and $408 \mathrm{~nm}$ - only photon counting).

Light is converted into an electrical current pulse by the photodetectors and recorded either as counts (photon counting), either as average current (analog). The most appropriate method for recording depends on the rate at which the photodetector produces output pulses, which is proportional to the intensity of the incident light. At high rates, photon counting detection is not recommended because the recorder is overwhelmed and cannot distinguish between simultaneous photons, thus underestimating the received signal. At low rates, the signal-to-noise ratio decreases significantly, thus the analogue detection becomes ineffective. For our system, the received signal is recorded by a transient recorder Licel TR-40, which has the advantage to combine the analogue part of the acquisition and photon counting part. It is comprised of a fast transient digitizer with on board signal averaging, a discriminator for single photon detection and a multichannel scaler combined with preamplifiers for both systems. In analogue detection the signal is amplified according to the input range selected and digitized by a 12-Bit20/40 MHz A/D converter.

At the same time, the signal part in the high frequency domain is amplified and a $250 \mathrm{MHz}$ fast discriminator detects single photon events above the selected threshold voltage. 64 different discriminator levels and two different settings of the preamplifier can be selected by using the acquisition software. The photon counting signal is written to a 16-Bit wide summation RAM which allows averaging of up to 4094 acquisition cycles. A more detailed description of the procedure can be found in Mielke (2013).

The signal inversion implies the use of the combined Raman-Mie procedure (Ansmann et al., 1992) in order to retrieve the aerosols optical parameters. Even though the backscatter and extinction coefficients profiles can be derived relatively without assumptions for Raman lidars (Pappalardo et al., 2004; Böckmann et al., 2005, 2012; Mamouri et al., 2012), the linear particle depolarization ratio depends on the

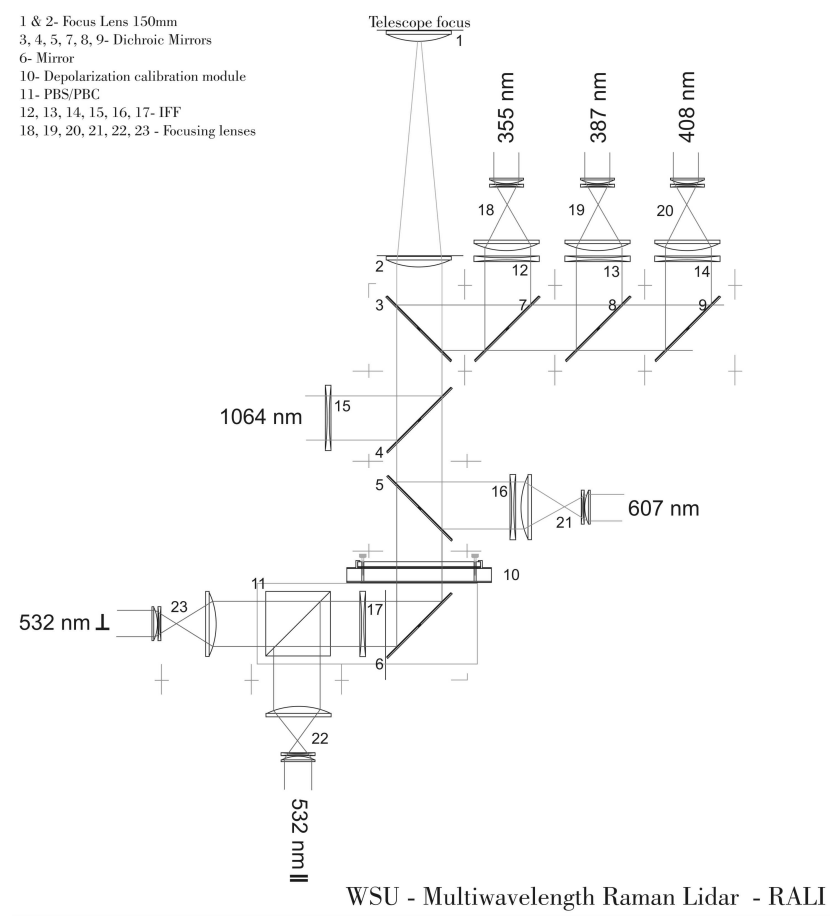

Fig. 1. Wavelength Separation Unit (WSU) of the multi-wavelength Raman lidar RALI.

accuracy of calibration and assumption of instrument's parameters. The calibration method used by RALI deploys consecutive measurements at $\pm 45^{\circ}$ angles between polarization plane of the laser beam and incident plane of the polarizing beam-splitter cube (PBC) (Freudenthaler et al., 2009). This method is used to assess for contributions of the detection chain to the final particle depolarization ratio profile. Measurements performed at exactly $90^{\circ}$ difference compensate each other for possible errors in the estimation of the angle. The $90^{\circ}$ difference between these measurements can be achieved with high accuracy by means of using a polarizing sheet filter in front of the PBC, motorized rotation mount or mechanical limit stops. The multi-wavelength Raman lidar uses a mechanical mount which allows the rotation of the $\mathrm{PBC}$ at $\pm 45^{\circ}$ in respect to the usual measuring position $\left(0^{\circ}\right)$ with an accuracy of less than $0.1^{\circ}$.

When retrieving $\delta^{\text {part }}$ with a non-ideal lidar system, several sources of systematic errors have to be considered: laser beam purity (i.e. polarization), influence of the emitting optics to the state of polarization of the emitted beam, imperfect separation of the two polarization components in the detection chain, filter performances (i.e. bandwidths, stability vs. temperature, angle of incidence) and also imperfection of the optical path (i.e. optical misalignments) (Behrendt and Nakamura, 2002). Calibration of the depolarization channels also has the role of correcting some of these limitations. Biele et al. (2000), Reichardt et al. (2003), Alvarez et al. (2006), Freudenthaler et al. (2009) showed how accurate 
depolarization observations can be realized using several calibration methods and corrections. The $\delta^{\text {part }}$ is estimated using the system dependent molecular-depolarization, estimated for a aerosol free region and used for the entire profile (Behrendt and Nakamura, 2002). For RALI system we assumed the molecular depolarization coefficient to be 0.02 for a $0.5 \mathrm{~nm}$ fwhm filter bandwidth.

\subsubsection{Sun photometer}

Worldwide sun photometers, part of AERONET (Aerosol Robotic Network) detect direct sun, aureole, and sky radiance (Holben et al., 1998). Bucharest site is active since 2007 and direct sun radiation is measured in eight channels from 340 to $1640 \mathrm{~nm}$. Sky radiation is obtained in four bands from 440 to $1020 \mathrm{~nm}$. From direct sun measurements the AOD (Aerosol Optical Depth) can be derived along with the Angström exponent. The inversion of sky radiance measurements within AERONET to obtain microphysical aerosol properties is described in details by several papers (e.g. Dubovik and King, 2000; Dubovik et al., 2006). The method also accounts for non-spherical particles by use of a spheroidal particle model and distinguishes fine-mode and coarse-mode particle fractions. Besides microphysical particle products, column values of the volume specific backscatter and extinction coefficients of the particles can be estimated. These volume-specific backscatter and extinction values are important input data for LIRIC (Wagner et al., 2013).

\subsection{Assessment of mass concentration}

Real aerosol in the atmosphere is a mixture of different components which result from different sources and processes. The number of combinations is unlimited, as both the chemical composition, and the proportion vary in time and space. Nevertheless, certain classifications are possible (see e.g. Dubovik et al., 2002) and the following four general aerosol classes are associated with different sources and are expected to have different optical properties (Chaikovsky et al., 2004): (i) continental (polluted) aerosol from fossil fuel combustion, (ii) biomass burning aerosol produced by forest and grass fires, (iii) desert dust blown into the atmosphere by wind and (iv) aerosol of marine origin. For each of these, sub-types can be defined.

In this study the multi-wavelength depolarization Raman lidar measurements were used to derive the backscatter coefficient profile without any assumption on the lidar ratio (LR). We used measured signals (the nitrogen Raman signals at $607 \mathrm{~nm}$ and the elastic backscatter signal at $532 \mathrm{~nm}$ cross and parallel) to compute the backscatter coefficients at $532 \mathrm{~nm}$ and the extinction coefficients at $532 \mathrm{~nm}$ (Ansmann et al., 1992), therefore the lidar ratio of the mixed aerosol profile. The cross and parallel polarized channels were used to calculate the particle depolarization profiles at $532 \mathrm{~nm}$, and further to separate the high and low depolarizing particles, contribution to the backscatter of the mixed aerosol (Tesche et al., 2009a). In order to separate the contribution of spherical and the non-spherical one using this method (described in details by Tesche et al., 2009a) is necessary to further assume an average $\delta^{\text {part }}$ specific for each component. The high depolarizing component, which can be desert or volcanic dust, has linear depolarization ratios varying between 25 and $35 \%$ (Mona et al., 2012; Burton et al., 2012; Shin et al., 2013). The low depolarizing component, usually smoke or urban aerosol, has linear depolarization ratios between 3-10\% (e.g. Burton et al., 2012). In this study we used $3 \%$ linear particle depolarization for urban/smoke component and $35 \%$ respectively for dust.

Extinction profiles of each component are calculated using the separated backscatter contribution and a constant typical LR for each component: $L R=35$ sr for pure dust and $L R=80$ sr for pure smoke). The typical values measured for pure dust $36.4 \pm 9.2 \mathrm{sr}$ were reported by Mona et al. (2012) from CALIOP data over North Africa. Tesche et al. (2011) measured LR values of $79 \pm 17 \mathrm{sr}$ at $532 \mathrm{~nm}$ for pure biomassburning aerosols transported from southern West Africa out over the Atlantic Ocean. Ansmann et al. (2009) measured LR values of 70-80 sr at 355 and $532 \mathrm{~nm}$ indicating the presence of fresh smoke. Further we consider OPAC-Optical Properties of Aerosols and Clouds software package (Hess et al., 1998) to obtain an estimation of characteristic optical properties (mass extinction efficiencies, Ångström coefficients) at different humidity's levels for each aerosol type. Most of the times in the atmosphere there is a mixture of particles of different origin. To describe the possible mixtures, the aerosol particles are considered made of different components, each related to a certain origin.

OPAC offers a database of microphysical and optical properties of 10 aerosol components (e.g in Fig. 2 mass extinction efficiencies and Ångström exponents (AE) at $70 \%$ relative humidity), both in the solar and terrestrial spectral range, and for 8 relative humidity conditions (i.e. $0 \%, 50 \%, 70 \%$, $80 \%, 90 \%, 95 \%, 98 \%, 99 \%)$ in the case of those aerosol components that are able to take up water. The optical properties of aerosols particles are modeled by OPAC under the assumption of sphericity.

Simulation and theoretical studies provide some reference values for different aerosol types also as a function of relative humidity (Veselovskii et al., 2010; Pahlow et al., 2006). The observed behaviour, dependent upon aerosol composition, may range from hygrophobic (e.g. mineral dust) to strongly hygroscopic (e.g. smoke).

Properties of the mineral dust are much less sensitive to increasing humidity than those of the smoke and volcanic dust aerosols (Nicolae et al., 2012). We modelled mineral dust transported by adding a variable proportion of mineral transported component to the OPAC's default mineral dust aerosol. To simulate volcanic dust aerosols, we added a variable proportion of sulfates to the default OPAC's type mineral dust. Mineral aerosol particles (desert) are assumed not 


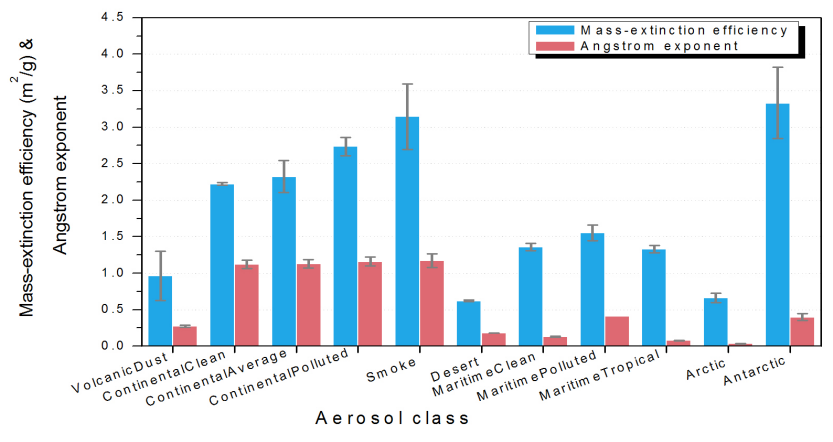

Fig. 2. Mass extinction efficiencies and Ångström coefficients for several aerosol classes as they were simulated using OPAC, relative humidity $70 \%$.

to enlarge with increasing relative humidity. Nevertheless, a small proportion of sulfates added to the mineral dust leads to an increase of the hygroscopic properties.

There is no particular aerosol type in OPAC which corresponds to biomass burning aerosols, the closest in terms of optical properties being the urban type. Urban aerosols contain a significant proportion of soot, used to represent absorbing black carbon, assumed not to grow with increasing relative humidity (Hess et al., 1998). Compared to urban aerosol, smoke is characterised by a high content of organics, other than soot, which are highly soluble. Therefore, the smoke was simulated by adding an increasing proportion of water soluble to the original urban aerosol. Values obtained with OPAC simulations are similar with the ones reported in the literature. In a review related to Lidar measurements of dust, Mona et al. (2012) presents Ångström exponents (extinction related) between 0 and 0.5 while Ansmann et al. (2003) focused on long range transported dust in the northern European regions and measured values close to 0.5. Papayannis et al. (2008) studied EARLINET dust climatology and found highly variable dust layers over Europe and mixed in different proportions with local, but AE typical 0.5-1. Ansmann et al. (2012) got AE of 0.29 for a case of Saharan dust observed over Leipzig.

Several measurements related to biomass burning aerosol are described in details in Nicolae et al. (2013) (and references within). For the confirmed biomass burning cases in this study, the Ångström exponents vary between 0.8 and 2 (Fig. 10 in Nicolae et al., 2013).

Clarke et al. (2004) found a typical mass scattering efficiency (a major component of the mass-extinction efficiency) for fine and coarse-mode dust $\sim 0.3 \mathrm{~m}^{2} \mathrm{~g}^{-1}$, and a mass absorption efficiency $\sim 0.009 \mathrm{~m}^{2} \mathrm{~g}^{-1}$, in measurements related to projects TRACE-P and ACE-Asia. Hand and Malm (2007) showed that the mass-scattering efficiency, varied from $1.2 \pm 0.3$ to $0.9 \pm 0.8 \mathrm{~m}^{2} \mathrm{~g}^{-1}$ from theoretical and experimental methods. Smoke mass extinction efficiencies between 2.2 to $4.0 \mathrm{~m}^{2} \mathrm{~g}^{-1}$ (at $633 \mathrm{~nm}$ ) were reported by Mulholland and Mountain (1999).

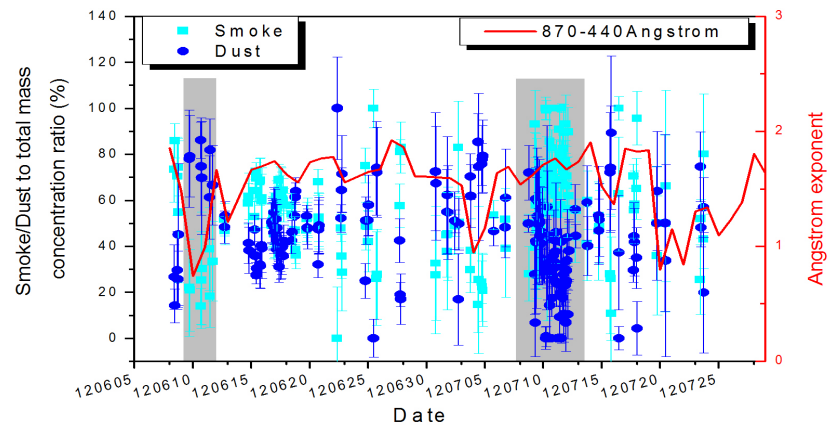

Fig. 3. Averaged values of smoke (and dust respectively) to total mass concentration ratio (in cyan and blue respectively) between 8 June and 30 July 2012; Ångström values are plotted in red; grey areas have been chosen for further analysis.

In this study we used the OPAC results at an average relative humidity (RH) of $70 \%$ since this was the most frequent $\mathrm{RH}$ value measured by our microwave radiometer during the studied period between 2 and $5 \mathrm{~km}$. The average mass extinction efficiency used for low-depolarizing component (smoke) is $3.14 \pm 0.43 \mathrm{~m}^{2} \mathrm{~g}^{-1}$ and $0.62 \pm 0.04 \mathrm{~m}^{2} \mathrm{~g}^{-1}$ for high-depolarizing component (mineral dust). OPAC results for $\mathrm{RH}=0 \%$ and $50 \%$ are presented in Fig. 1 of Nicolae et al. (2012).

\section{Results}

\subsection{Case studies}

The method developed for the retrieval of the partial and total mass concentration profiles is useful to study special cases such as Saharan dust outbreaks and biomass burning events, and also to study seasonal variability of local aerosol.

Figure 3 presents the results of almost two months of measurements during June-July 2012. Measurements considered have been first cleared for clouds. On the measured signal at $532 \mathrm{~nm}$ we used a Haar wavelet algorithm and set a threshold for separating the generally sharper cloud edges from the less pronounced aerosol feature boundaries in each lidar profile (Talianu et al., 2006; Belegante et al., 2013). Profiles with low clouds (below $5 \mathrm{~km}$ ) were excluded from the average. Each vertical profile represents the average of one hour measurements, separated on the two components. Smoke to total mass concentration ratio profile $\left(r_{\mathrm{s}}\right)$ and dust to total mass concentration ratio profile $\left(r_{\mathrm{d}}\right)$ have been calculated for each profile in order to observe the dominance of each aerosol type. Figure 3 shows the mean values of $r_{\mathrm{d}}$ and $r_{\mathrm{s}}$ (average of each profile) from 8 June to 30 July 2012. The error bars represents the uncertainties propagated through the algorithm.

Ångström exponents derived from sunphotometer measurements during the same period are plotted in red. Two cases have been highlighted in grey: 10 June and 12 July. High Dust concentrations and Ångström values below 1 are 

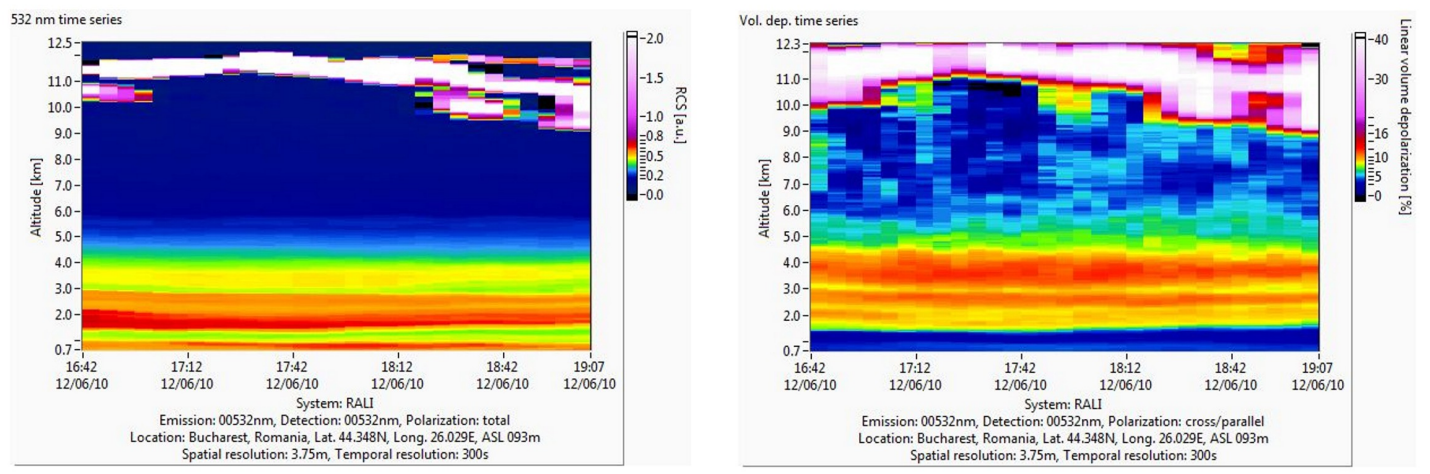

Fig. 4. Temporal evolution of the lidar range corrected signal at $532 \mathrm{~nm}$ (left panel) and linear volume depolarization ratio at $532 \mathrm{~nm}$ (right panel) for 10 June 2012, 16:42-19:07 UTC, measured at Magurele lidar station.

the characteristics for the first case, while smoke and high Ångström values (1.5-1.7) dominates during the second one.

For the first case study, Fig. 4 presents times series of the RCS (Range corrected signal, left panel) and linear volume depolarization ratio (right panel) obtained for 10 June 2012, when dense and persistent Saharan dust air masses were present above the lidar station, below $5 \mathrm{~km}$. A cirrus cloud is also visible above $10 \mathrm{~km}$.

Backtrajectory analysis using the online HYSPLIT tool from the NOAA Air Resources Laboratory READY website (Draxler and Rolph, 2012) (http://ready.arl.noaa.gov/ HYSPLIT.php) show that layers at 2, 3 and $4 \mathrm{~km}$ were originating from NW Sahara regions four days before (Fig. 5 left panel). DREAM (Dust REgional Atmospheric Model) forecast (Basart et al., 2012) shows a forecast of dust intrusion over Romania on 10 June (Fig. 5 right panel).

With this confirmation, we assume that the highdepolarizing component of the mixed aerosol is typical mineral dust (Fig. 6a and b), and using the mass-extinction efficiency for this aerosol type, we obtained the mass concentration profiles (Fig. 6c).

Total backscatter coefficient and its separation due to different depolarization (smoke and dust) along with extinction related Ångström exponent and linear particle depolarization ratio for 10 June 2012 are presented in Fig. 6a and b respectively. Values of the extinction-related Angström exponent are less than 0.5 between 2 and $4 \mathrm{~km}$ (similar to the value measured by sun photometer, Fig. 3), while $\delta^{\text {part }}$ is about $20 \%$ in the same altitude range, consistent with characteristics of mineral dust transported.

In Fig. $6 \mathrm{c}$ it can be seen that up to $1.1 \mathrm{~km}$ and above $5 \mathrm{~km}$, the mass concentration of smoke and dust are almost equal. In the $2-4.5 \mathrm{~km}$ range, dust is predominant. With a peak between 2 and 4, DREAM is not capturing the correct limits and the substructure of the layer (not shown), but vertical profiles of coarse spheroids and fine spherical derived using LIRIC algorithm (Fig. 6d) agree well (both the shape and the values) with the retrievals from our algorithm (Fig. 6c).
The second study case is presented in Fig. 7. Times series of the RCS (left panel) and linear volume depolarization ratio (right panel) obtained for 12 July 2012 depict a layer between 3 and $4 \mathrm{~km}$.

The air mass back-trajectory analysis (Fig. 8 left panel) indicated that the air masses sampled at 1 and $3.5 \mathrm{~km}$ heights passed over regions with high biomass burning events (identified as hot-spot areas by MODIS on board the Terra and Aqua satellites over a 10-day period of Fire data between 918 July 2012 (Fig. 8 right panel), during the three days prior to reaching Bucharest observational site.

Lidar measurements in the identified layer between 3$4 \mathrm{~km}$ height (Fig. 9a) found high Ångström values $(1.5-$ 2.0 ) and linear depolarization ratios values between 3-4\% (Fig. 9b) indicating the presence of smoke but mixed with small urban polluted particles, as similarly observed by Müller et al. (2005), Amiridis et al. (2009), and Tesche et al. (2011). Mass concentrations retrieved for this particular case reached a maximum of about $50 \mu \mathrm{g} \mathrm{m}^{-3}$ for the aerosol classified as smoke, while dust component is down to less than $10 \mu \mathrm{g} \mathrm{m}^{-3}$ (Fig. 9c). These results are similar to the ones obtained by using LIRIC algorithm for 12 July 2012 (Fig. 9d). Even though small differences can be observed, the results can be considered comparable considering the high complexity of these different methods but both using optical data from lidar.

Depolarization values measured by us correspond with aerosol types from previous studies. Burton et al. (2012) classified measurements from 2006 to 2012 made by high spectral resolution lidar and considered depolarization ratio for dusty mix $13-20 \%$, for pure dust $30-35 \%$, while for smoke 4-9\%. Murayama et al. (2004) measured Siberian smoke over Japan and found $\delta^{\text {part }} 5-8 \%$. Results from Shin et al. (2013) indicate for pure Asian dust depolarization ratio of $27 \%$, mixed dust $16 \%$, while Ansmann et al. (2012) observed Saharan dust over Leipzig with depolarization ratio of $30 \%$. 

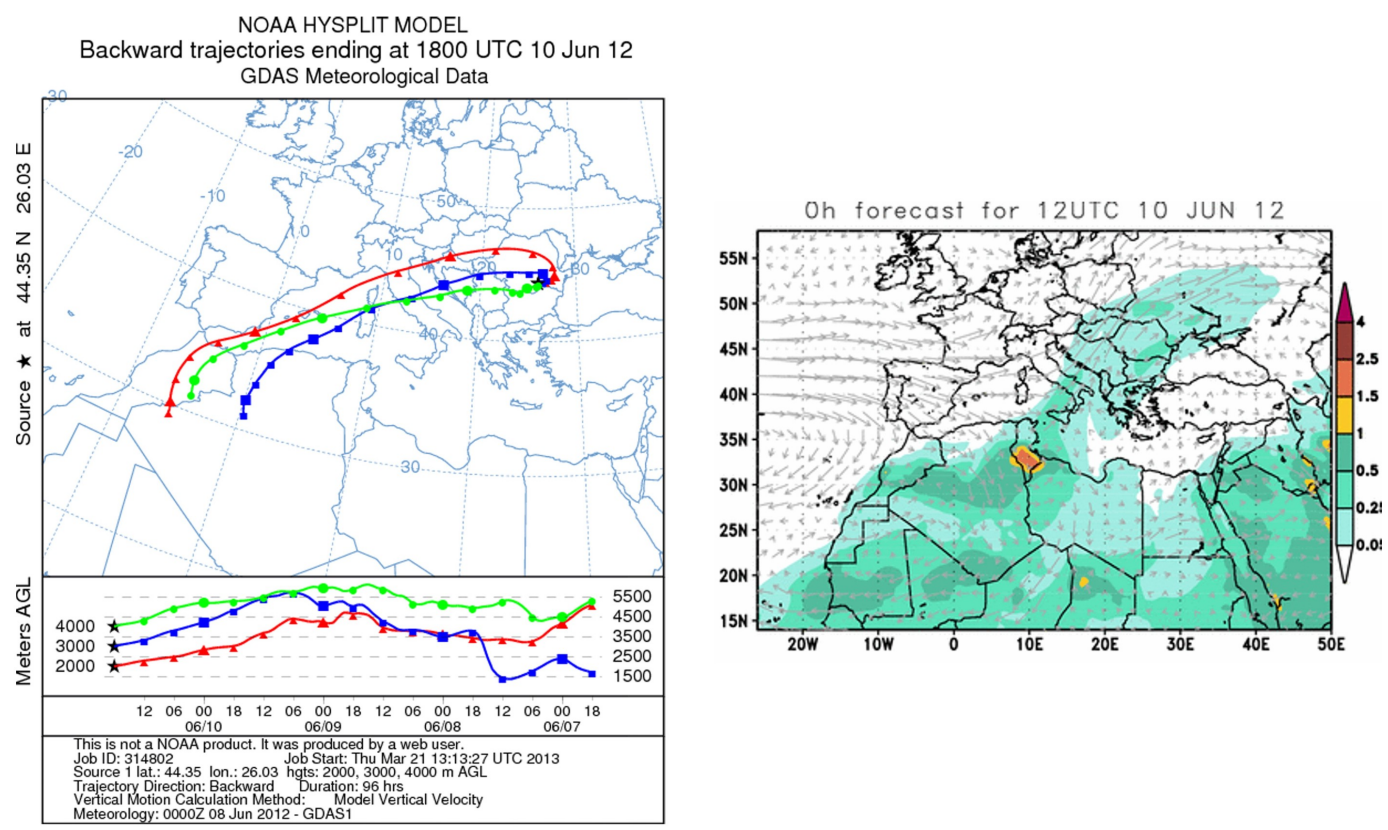

Fig. 5. The result from $96 \mathrm{~h}$ back trajectories displaying the air mass source for 10 June 2012 at aerosol layer of the altitude $2000 \mathrm{~m}, 3000 \mathrm{~m}$ and $4000 \mathrm{~m}$ (red line, blue line and green line, left). DREAM dust loading forecast (right panel) for same day, at 12:00 UTC; the arrows indicate wind direction at $3 \mathrm{~km}$.
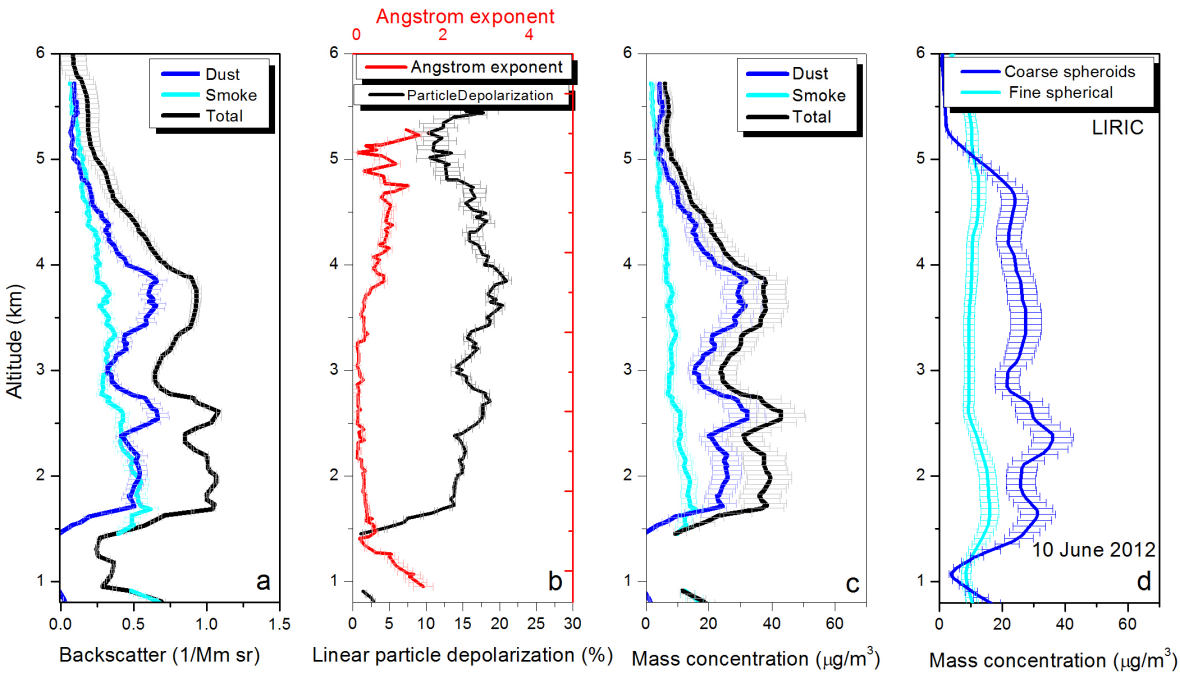

Fig. 6. Results for 10 June 2012 - (a) total backscatter coefficient at $532 \mathrm{~nm}$ and its separation due to different depolarization (smoke and dust); (b) black line is the measured linear particle depolarization ratio and the red line is the extinction-related Ångström exponent (355$532 \mathrm{~nm}$ ); (c) Total mass concentration and its separation on different components using lidar data and OPAC; Profiles are averaged over one hour 18:44-19:44 UTC; The overlap height is $800 \mathrm{~m}$. The errors bars correspond to the statistical uncertainty propagated through the inversion chain. (d) Coarse spheroids (blue) and fine spherical (cyan) separation retrieved using LIRIC.

\subsection{Seasonal variability of local aerosol}

We applied the described method to calculate mass concentration profiles (each from one hour averaged measurements) for several datasets collected during winter and summer. Data were collected at Magurele, Romania $\left(26.029^{\circ} \mathrm{E}, 44.048^{\circ} \mathrm{N}\right.$,
$93 \mathrm{~m}$ above sea level). The measurement site is a typical continental polluted, influenced mainly by traffic and construction industry, and combined with agricultural activities. Long-range transport generally occurs from East and North East Europe during winters and South and West Europe during summers. 

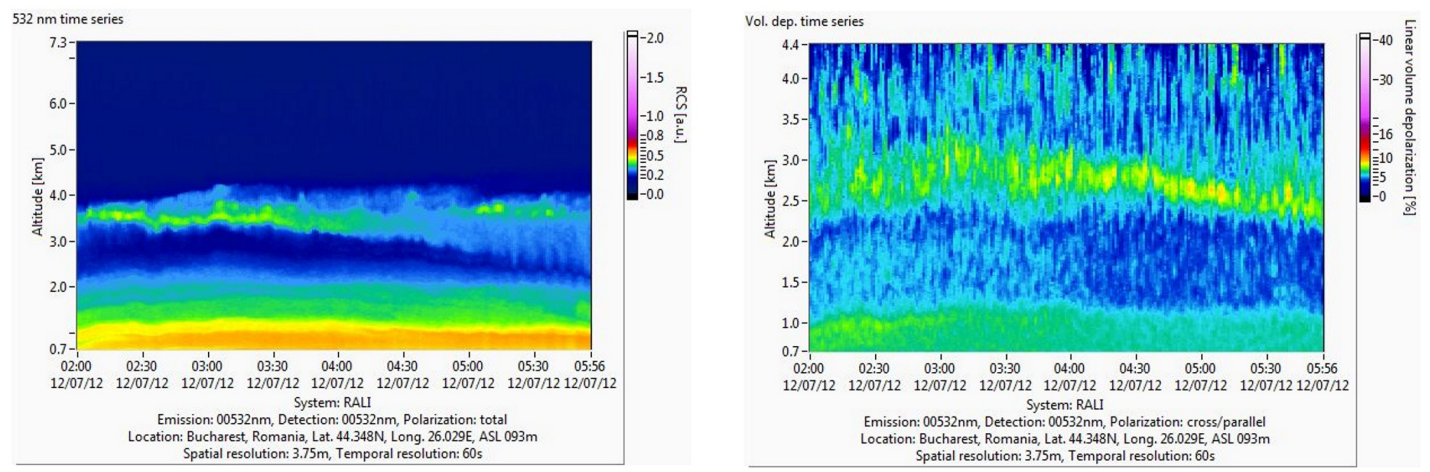

Fig. 7. Same as in Fig. 3 but for 12 July 2012, 02:00-5:56 UTC.
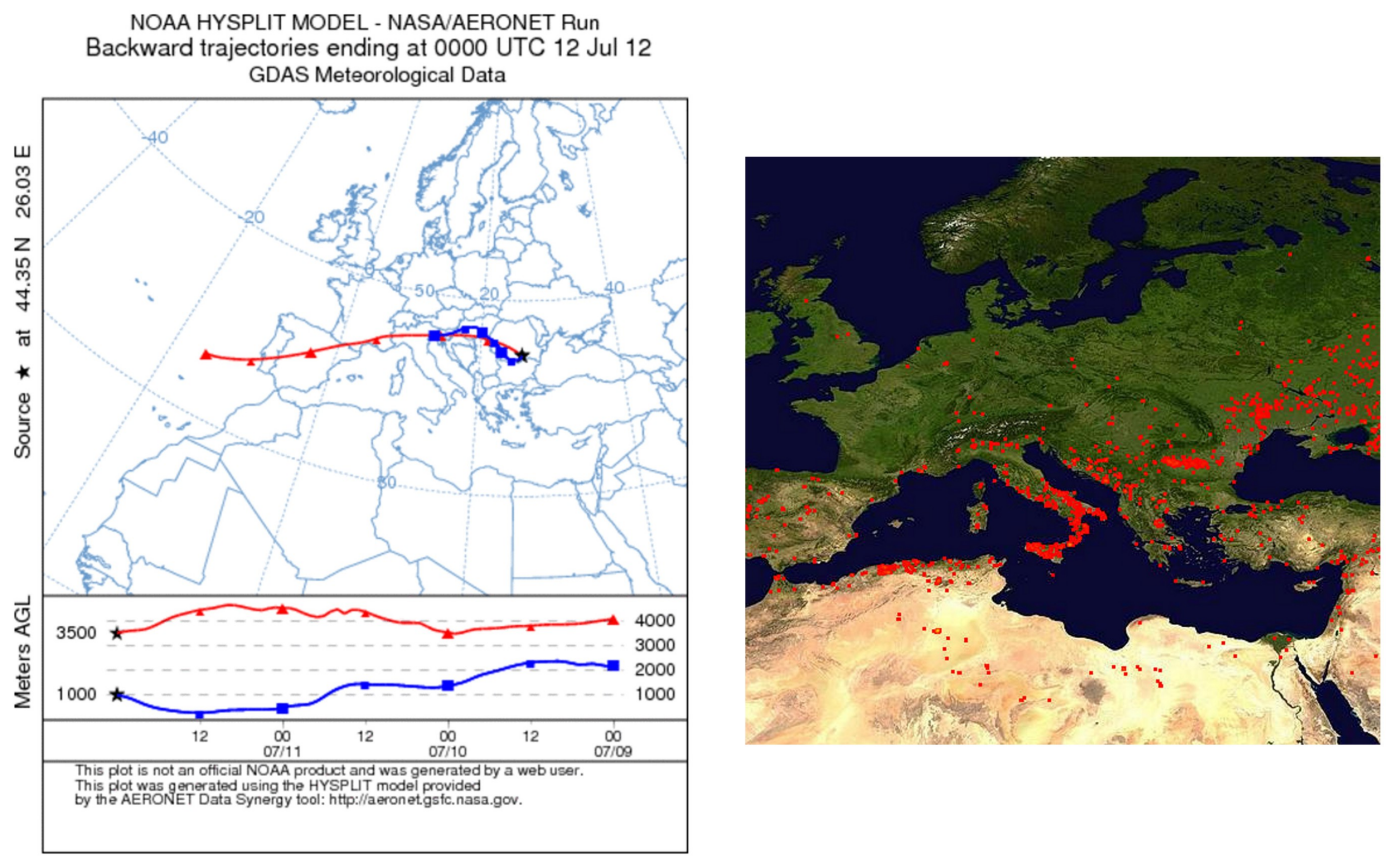

Fig. 8. The result from $72 \mathrm{~h}$ back trajectories displaying the air mass arriving on 12 July 2012 at aerosol layer of the altitude $1000 \mathrm{~m}$ and $3500 \mathrm{~m}$ (blue line and red line each, left panel). Fire areas depicted by MODIS 10 days composite images between 9 and 18 July 2012 (right panel).

Lidar measurements between June 2012 and April 2013 were used to retrieve mass concentration profiles, considering urban/smoke as low-depolarizing component, and mineral dust as high-depolarizing component. One hour averaged profiles are shown in Fig. 10.

An increased of the total mass concentration during summer time is observed at all altitudes even though this increase is more pronounced at altitudes higher than $2 \mathrm{~km}$. Both in summer and winter mineral dust is mixed with urban/smoke, although the proportions are variable.

Long-range transported mineral dust is often present at 2.5 to $5 \mathrm{~km}$ during the hot season, when the general air mass circulation is predominant from Southern regions, collecting mineral dust particles either directly from North Africa, either indirectly from South-East or South-West Europe (e.g. Nicolae et al., 2008; Papayannis et al., 2008). Increased mineral dust mass concentration is nevertheless noticed during summer at all altitudes, including in the boundary layer. This is due to increased traffic combined with the heating of the ground surfaces, generating turbulent fluxes which lift small dust particles from the soil. The construction sites nearby are also more active during the hot season, as well as the agricultural activities. Generally, soil dust consists of mineral particles with a small fraction of organic matter. In contrast to desert soil, which is low in organic content, agricultural land use is concentrated on fertile soils with much larger organic matter contents. Air movements preferentially transport small soil particles, which carry above average loads of 

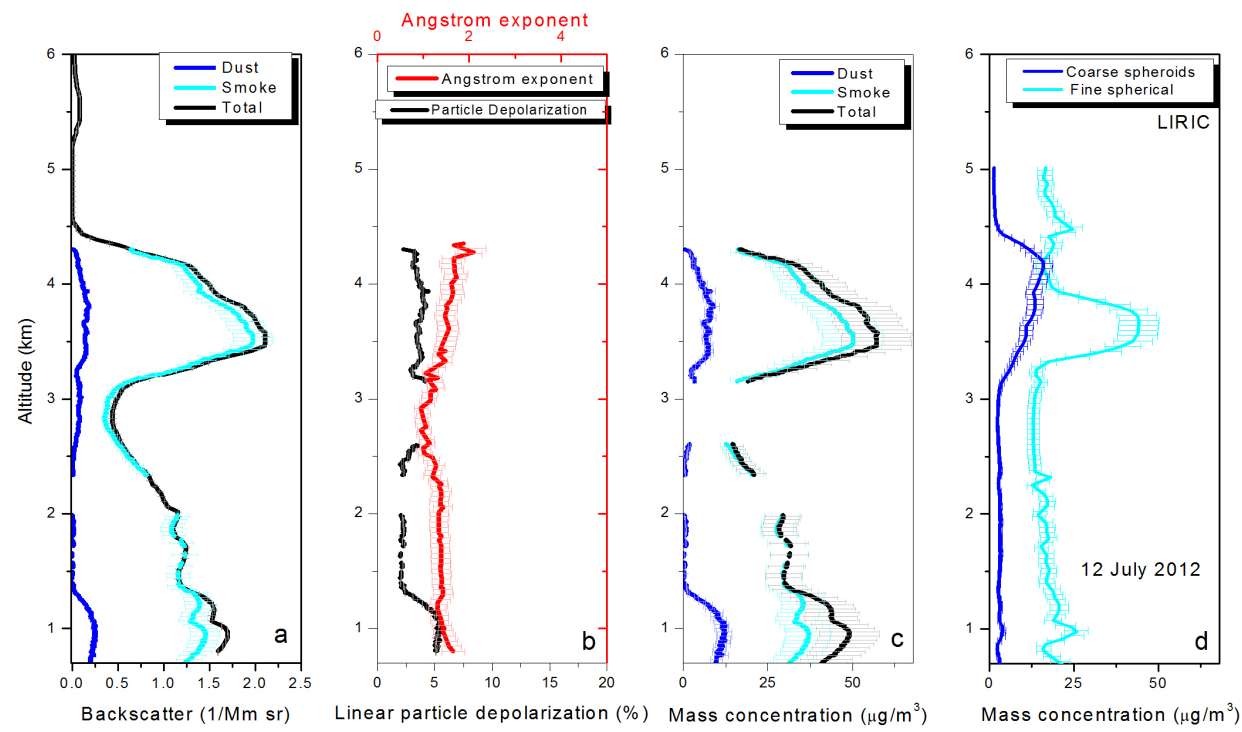

Fig. 9. Same as in Fig. 6 but for 12 July 2012, averaged over one hour 03:00-04:00 UTC.

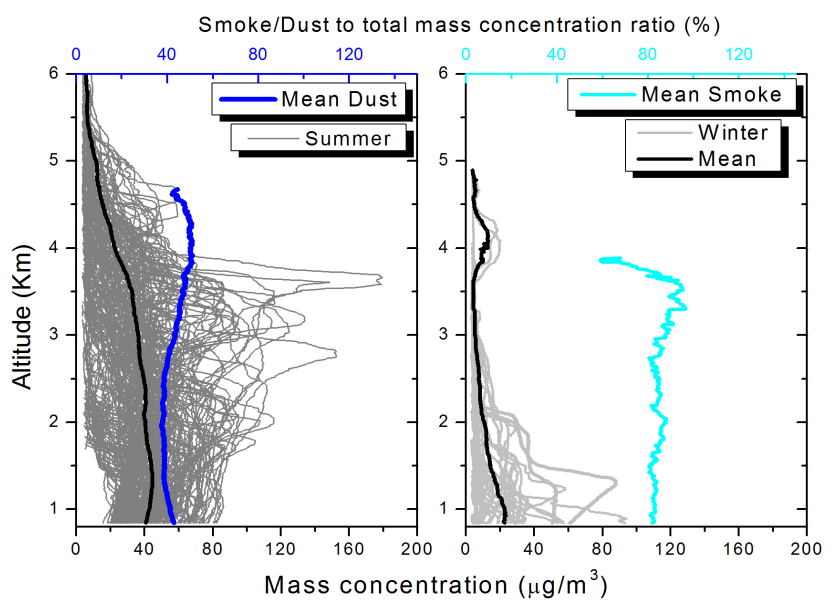

Fig. 10. Total mass concentration profiles during summer (gray lines left panel) and winter (grey lines right panel); black lines in both panels represent the mean seasonal representative profile; blue line (left panel) is the mean dust to total mass concentration ratio for hot season, while cyan line is the mean smoke to total mass concentration for cold season.

biological residues (Hoffmann et al., 2008). Therefore, the dust aerosol considered in our study is in fact a mixture of mineral and soil dust, with potential different properties. It is, for example, known that small amounts of biological residues can greatly enhance the number of ice nucleation sites of the soil dust. The soil in the measurement region is characterised by small organic matter content (Avram, 2013). As such, we considered that the assumptions made for the mineral dust are still valid.

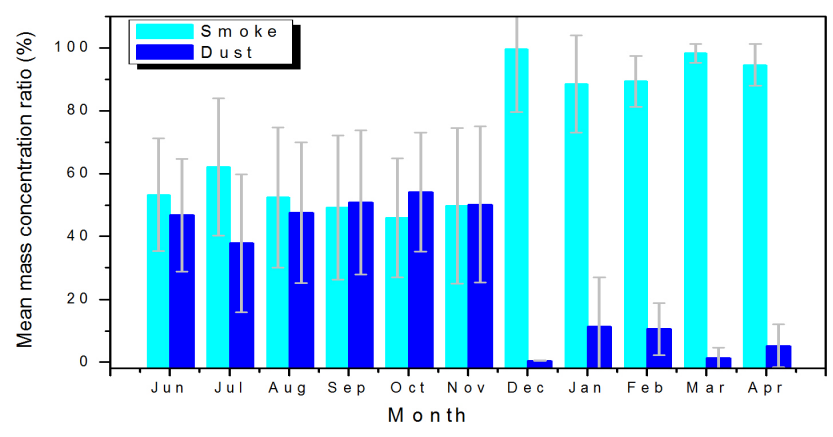

Fig. 11. Monthly variation of the mean dust (and smoke)-to-mass concentration ratios (blue and cyan, respectively). The standard deviation (grey bars) is the measure of the variability of the individual mean values.

The situation is different in winter, when the ratio of dust to the total mass concentration decreases. Combustion products from heating contribute significantly to the smoke component, which becomes the major component of the aerosols (Fig. 10 right panel and Fig. 11). Precipitation and snow cover also contribute to the decrease of the dust component.

Figure 11 shows the monthly mean of the dust (and smoke)-to-mass concentration ratios (blue and cyan, respectively) during June 2012-April 2013. In December 2012 smoke starts to be the dominant component due to the pronounced increase in house heating in Magurele, but also due to heavy precipitations. Circulation patterns over Europe during December 2012-April 2013 suppressed transport of dust over long distances. 


\section{Discussions and conclusions}

Mass concentration profiles for mixed aerosols have been calculated from multi-wavelength depolarization Raman measurements, by considering low and high depolarizing components along with OPAC data. The mixture consists of two components with significantly different depolarization properties, e.g. urban/smoke and mineral dust. Variations of the proportions of the internally mixed components for different aerosol classes and their effect on the mass-extinction ratio and Angstrom coefficient were calculated in OPAC at $70 \%$ relative humidity. Simulations showed that the mass-extinction ratio for urban/smoke-type aerosol is $3.14 \pm 0.43 \mathrm{~m}^{2} \mathrm{~g}^{-1}$ and for dust mineral transported is $0.62 \pm 0.04 \mathrm{~m}^{2} \mathrm{~g}^{-1}$.

Two study cases are presented. Mass concentration profiles were retrieved for a Saharan dust intrusion event and long range transported smoke. Clear separation of low and high depolarizing particle concentrations were obtained using Lidar-OPAC algorithm. Similar results were found using the LIRIC algorithm.

The analysis highlighted also the seasonal variability of local aerosol. The mineral dust dominates over the anthropogenic/smoke aerosols during summer while during winter the mineral dust proportion is much less. An increased of the total mass concentration during summer time is observed at all altitudes. For all cases, the method was able to separate between highly depolarizing and low depolarizing particles, and to provide the total mass concentration, based on a combination of measured and modeled parameters.

This study shows that the retrieval of mass concentration profiles from multi-wavelength depolarization Raman lidar measurements is possible, but dependent on an appropriate calibration of the depolarization and careful selection of the mass-extinction efficiencies in OPAC. Main advantage of this method is that is simple and fast, providing sufficient information for real time assessment.

Acknowledgements. This work has been supported by the FP7INFRASTRUCTURES-2010-1 under grant 262254 - ACTRIS, by a Romanian grant PN-II-RU-PD-2011-3-0082 and by a grant of the STAR-ESA Programme 38/2012-CAPESA.

Data and/or images from the BSC-DREAM8b (Dust REgional Atmospheric Model) model, operated by the Barcelona Supercomputing Center (http://www.bsc.es/projects/earthscience/ BSC-DREAM)

Edited by: G. Pappalardo

\section{References}

Alvarez, J. M., Vaughan, M. A., Hostetler, C. A., Hunt, W. H., and Winker, D. M.: Calibration technique for polarization-sensitive lidars, J. Atmos Ocean. Tech., 23, 683-699, 2006.

Amiridis, V., Balis, D. S., Giannakaki, E., Stohl, A., Kazadzis, S., Koukouli, M. E., and Zanis, P.: Optical characteristics of biomass burning aerosols over Southeastern Europe determined from UVRaman lidar measurements, Atmos. Chem. Phys., 9, 2431-2440, doi:10.5194/acp-9-2431-2009, 2009.

Amiridis, V., Balis, D., Giannakaki, E., Kazadzis, S., Arola, A., and Gerasopoulos, E.: Characterization of the aerosol type using simultaneous measurements of the lidar ratio and estimations of the single scattering albedo, Atmos. Res., 101, 46-53, 2011.

Ansmann, A., Riebesell, M., Wandinger, U., Weitkamp, C., Voss, C., Lahmann, W., and Michaelis, W.: Combined Raman elastic backscatter lidar for vertical profiling of moisture, aerosol extinction, backscatter, and lidar ratio, Appl. Phys. B, 55, 18-28, 1992.

Ansmann, A., Bosenberg, J., Chaikovsky, A., Comeron, A., Eckhardt, S., Eixmann, R., Freudenthaler, V., Ginoux, P., Komguem, L., Linne, H., Lopez, M. A., Matthias, V., Mattis, I., Mitev, V., Muller, D., Music, S., Nickovic, S., Pelon, J., Sauvage, L., Sobolewsky, P., Srivastava, M. K., Stohl, A., Torres, O., Vaughn, G., Wandinger, U., and Wiegner, M.: Long-range transport of Saharan dust to Northern Europe: the 11-16 October 2001 outbreak observed with EARLINET, J. Geophys. Res., 108, 4783, doi:10.1029/2003JD003757, 2003.

Ansmann, A., Baars, H., Tesche, M., Muller, D., Althausen, D., Engelmann, R., Pauliquevis, T., and Artaxo P.: Dust and smoke transport from Africa to South America: Lidar profiling over Cape Verde and the Amazon rainforest, Geophys. Res. Lett., 36, L11802, doi:10.1029/2009GL037923, 2009.

Ansmann, A., Seifert, P., Tesche, M., and Wandinger, U.: Profiling of fine and coarse particle mass: case studies of Saharan dust and Eyjafjallajökull/Grimsvötn volcanic plumes, Atmos. Chem. Phys., 12, 9399-9415, doi:10.5194/acp-12-9399-2012, 2012.

Avram, C. C.: PAAR Ilfov 2013, report of local authorities related to Ilfov county, available at: www.isuilfov.ro, last access: 26 November 2013 (in Romanian).

Basart, S., Perez, C., Nickovic, S., Cuevas, E., and Baldasano, J. M.: Development and evaluation of the BSCDREAM8b dust regional model over Northern Africa, the Mediterranean and the Middle East, Tellus B, 64, 18539, doi:10.3402/tellusb.v64i0.18539, 2012.

Belegante, L., Nicolae, D., Nemuc, A., Talianu, C., and Derognat, C.: Retrieval of the boundary layer height from active and passive remote sensors, Comparison with a NWP model, Acta Geophysica, online first, doi:10.2478/s11600-013-0167-4, 2013.

Behrendt, A. and Nakamura, T.: Calculation of the calibration constant of polarization lidar and its dependency on atmospheric temperature, Opt. Express, 10, 805-817, 2002.

Biele, J., Beyerle, G., and Baumgarten, G.: Polarization lidar: corrections of instrumental effects, Opt. Express, 7, 427-435, 2000.

Böckmann, C., Mironova, I., Muller, D., Schneidenbach, L., and Nessler, R.: Microphysical aerosol parameters from multiwavelength lidar, J. Opt. Soc. Am. A, 22, 518-528, 2005.

Böckmann, C., Osterloh, L., Rother, T., Serikov, I., Linne, H., and Kinne, S.: Optical and microphysical properties from Raman lidar and depolarization data, Reviewed and Revised Papers Pre- 
sented at the 26th International Laser Radar Conference (ILRC 2012), 415-418, 2012.

Burton, S. P., Ferrare, R. A., Hostetler, C. A., Hair, J. W., Rogers, R. R., Obland, M. D., Butler, C. F., Cook, A. L., Harper, D. B., and Froyd, K. D.: Aerosol classification using airborne High Spectral Resolution Lidar measurements - methodology and examples, Atmos. Meas. Tech., 5, 73-98, doi:10.5194/amt-5-73-2012, 2012.

Chaikovski, A., Bril, A., Dubovik, O., Holben, B., Thompson, A., Goloub, P., O’Neill, N., Sobolewski, P., Bösenberg, J., Ansmann, A., Wandinger, U., and Mattis, I.: CIMEL and multi-wavelength lidar measurements for troposphere aerosol altitude distributions investigation, long-range transfer monitoring and regional ecological problems solution: field validation of retrieval techniques, Optica Pura y Aplicada, 37, 3241-3246, 2004.

Clarke, A. D., Shinozuka, Y., Kapustin, V. N., Howell, S., Huebert, B., Doherty, S., Anderson, T., Covert, D., Anderson, J., Hua, X., Moore II, K. G., McNaughton, C., Carmichael, G., and Weber, R.: Size distributions and mixtures of dust and black carbon aerosol in Asian outflow, Physiochemistry and optical properties, J. Geophys. Res., 109, D15S09, doi:1029/2003JD004, 2004.

Draxler, R. R. and Rolph, G. D.: HYSPLIT (HYbrid Single-Particle Lagrangian Integrated 297 Trajectory) Model access via NOAA ARL READY Website 298, available at: http://ready.arl.noaa. gov/HYSPLIT.php, NOAA Air Resources Laboratory, Silver Spring, MD. 299, 2012.

Dubovik, O. and King, M. D.: A flexible inversion algortihm for retrieval of aerosol optical properties from Sun and sky radiance measurements, J. Geophys. Res., 105, 20673-20696, 2000.

Dubovik, O., Holben, B. N., Eck, T. F., Smirnov, A., Kaufman, Y. J., King, M. D., Tanré, D., and Slutsker, I.: Variability of absorption and optical properties of key aerosol types observed in worldwide locations, J. Atmos. Sci., 59, 590-608, 2002.

Dubovik, O., Sinyuk, A., Lapyonok, T., Holben, B. N., Mishchenko, M., Yang, P., Eck, T. F., Volten, H., Munoz, O., Weihelmann, B., van der Zande, W. J., Leon, J.-F., Sokorin, M., and Slutsker, I.: Application of spheroid models to account for aerosol particle nonspericity in 25 remote sensing of desert dust, J. Geophys. Res., 11, D11208, doi:10.1029/2005JD006619, 2006.

Dubovik, O., Pappalardo, G., Wandinger, U., Apituley, A., Alados, Arbroledas, L., Papayannis, A., and Pietruczuk, A.: Algorithm and Software for the Retrieval of Vertical Aerosol Properties using combined Lidar/Radiometer Data, Reviewed and Revised Papers Presented at the 26th International Laser Radar Conference (ILRC 2012), 339-402, 2012.

Fernald, F. G., Herman, B. M., and Reagan, J. A.: Determination of Aerosol height distributions by Lidar, J. Appl. Meteorol., 11, 482-489, 1972.

Freudenthaler, V., Esselborn, M., Wiegner, M., Heese, B., Tesche, M., Ansmann, A., Mueller, D., Althausen, D., Wirth, M., Fix, A., Ehret, G., Knippertz, P., Toledano, C., Gasteiger, J., Garhammer, M., and Seefeldner, M.: Depolarization-ratio profiling at several wavelengths in pure Saharan dust during SAMUM 2006, Tellus B, 61, 165-179, 2009.

Gasteiger, J., Groß, S., Freudenthaler, V., and Wiegner, M.: Volcanic ash from Iceland over Munich: mass concentration retrieved from ground-based remote sensing measurements, Atmos. Chem. Phys., 11, 2209-2223, doi:10.5194/acp-11-22092011, 2011.
Gobbi, G. P.: Polarization Lidar Returns from Aerosols and Thin Clouds: a Framework for the Analysis, Appl. Optics, 37, 55055508, 1998.

Hand, J. L. and Malm, W. C.: Review of aerosol mass scattering efficiencies from ground-based measurements since 1990, J. Geophys. Res., 112, D16203, doi:10.1029/2007JD008484, 2007.

Heese, B. and Wiegner, M.: Vertical aerosol profiles from Raman polarization lidar observations during the dry season AMMA field campaign, J. Geophys. Res., 113, D00C11, doi:10.1029/2007JD009487, 2008.

Hervo, M., Quennehen, B., Kristiansen, N. I., Boulon, J., Stohl, A., Fréville, P., Pichon, J.-M., Picard, D., Labazuy, P., Gouhier, M., Roger, J.-C., Colomb, A., Schwarzenboeck, A., and Sellegri, K.: Physical and optical properties of 2010 Eyjafjallajökull volcanic eruption aerosol: ground-based, Lidar and airborne measurements in France, Atmos. Chem. Phys., 12, 17211736, doi:10.5194/acp-12-1721-2012, 2012.

Hess, M., Koepke, P., and Schult, I.: Optical Properties of Aerosols and Clouds: The Software Package OPAC, Bulletin of the American Meteorological Society, 79, 831-844, 1998.

Hogan, R. J., Haywood, J. M., Westbrook, C. D., Dacre, H. F., Marenco, F., O'Connor, E. J., Johnson, B. T., Wrench, C. L., and Belcher S. E.: Combined lidar and sunphotometer retrievals of ash particle size and mass concentration from the Eyjafjallajokull volcano, J. Geophys. Res., in preparation, 2013.

Hoffmann, C., Funk, R., Li, Y., and Sommer, M.: Effect of grazing on wind driven carbon and nitrogen ratios in the grasslands of Inner Mongolia, Catena, 75, 182-190, 2008.

Holben, B. N., Eck, T. F., Slutsker, I., Tanre, D., Buis, J. P., Setzer, A., Vermote, E., Reagan, J. A., Kaufman, Y. J., Nakajima, T., Lavenu, F., Jankowiak, I., and Smirnov, A.: AERONET - A federated instrument network and data archive for aerosol characterization, Remote Sens. Environ., 66, 1-16, 1998.

Klett, J. D.: Stable Analytical Inversion Solution For Processing Lidar Returns, Appl. Optics, 20, 211-220, 1981.

Kovalev, V. and Eichinger, V.: Elastic lidar: Theory, Practice and Analysis Methods, Wiley Interscience Publ., New York, USA, 2004.

Lesins, G., Chylek, P., and Lohmann, U.: A study of internal and external mixing scenarios and its effect on aerosol optical properties and direct radiative forcing, J. Geophys. Res., 107, AAC5.1AAC5.12, doi:10.1029/2001JD000973, 2002.

Mamouri, R. E., Papayannis, A., Amiridis, V., Müller, D., Kokkalis, P., Rapsomanikis, S., Karageorgos, E. T., Tsaknakis, G., Nenes, A., Kazadzis, S., and Remoundaki, E.: Multi-wavelength Raman lidar, sun photometric and aircraft measurements in combination with inversion models for the estimation of the aerosol optical and physico-chemical properties over Athens, Greece, Atmos. Meas. Tech., 5, 1793-1808, doi:10.5194/amt-5-1793-2012, 2012.

Mielke, B.: Analogue + Photon Counting Bernd, available at: http: //www.licel.com/analogpc.pdf, last access: 26 November 2013.

Mona, L., Liu, Z., Müller, D., Omar, A., Papayannis, A., Pappalardo, G., Sugimoto, N., and Vaughan, M.: Lidar Measurements for Desert Dust Characterization: An Overview, Advances in Meteorology, 2012, 356265, doi:10.1155/2012/356265, 2012.

Mulholland, G. and Mountain, R.: Coupled dipole calculation of extinction coefficient and polarization ratio for smoke agglomerates, Combust. Flame, 119, 56-68, 1999. 
Müller, D., Mattis, I., Wandinger, U., Ansmann, A., Althausen, D., Dubovik, O., Eckhardt, S., and Stohl, A.: Saharan dust over a central European EARLINET-AERONET site: Combined observations with Raman lidar and Sun photometer, J. Geophys. Res., 108, 4345, doi:10.1029/2002JD002918, 2003.

Müller, D., Mattis, I., Wandinger, U., Ansmann, A., Althausen, D., and Stohl, A.: Raman lidar observations of aged Siberian and Canadian forest fire smoke in the free troposphere over Germany in 2003: Microphysical particle characterization, J. Geophys. Res., 110, D17201, doi:10.1029/2004JD005756, 2005.

Murayama, T., Muller, D., Wada, K., Shimizu, A., Sekiguchi, M., and Tsukamoto, T.: Characterization of Asian dust and Siberian smoke with multi-wavelength raman lidar over Tokyo, Japan in spring 2003, Geophys. Res. Lett., 31, L23103, doi:10.1029/2004GL021105, 2004.

Nicolae, D., Talianu, C., Mamouri, R. E., Carstea, E., Papayannis, A., and Tsaknakis, G.: Air mass modification processes over the Balkans area detected by aerosol lidar techniques, Optoelectron. Adv. Mat., 2, 394-402, 2008.

Nicolae, D., Vasilescu, J., and Carstea, E.: Estimation Of Mass Concentration Profiles For 2-Components External Mixtures Of Aerosols, Based On Multi-wavelength Depolarization Lidar, Proceedings of the 9th International Symposium on Tropospheric Profiling, Session C, ISBN/EAN:978-90-815839-4-7, available at: http://cetemps.aquila.infn.it/istp/proceedings/ Session_C_Aerosols_clouds_and_precipitation/Session_C_ Wednesday_5_September_2012/SC_08_Nicolae.pdf ${ }^{-}$(last access: 25 November 2013), 2012.

Nicolae, D., Nemuc, A., Müller, D., Talianu, C., Vasilescu, J., Belegante, L., and Kolgotin, A.: Characterization of fresh and aged biomass burning events using multi-wavelength Raman lidar and mass spectrometry, J. Geophys. Res. Atmos., 118, 2956-2965, doi:10.1002/jgrd.50324, 2013.

Pahlow, M., Feingold, G., Jefferson, A., Andrews, E., Ogren, J. A., Wang, J., Lee, Y.-N., Ferrare, R. A., and Turner, D. D.: Comparison between lidar and nephelometer measurements of aerosol hygroscopicity at thesouthern great plains atmospheric radiation measurement site, J. Geophys. Res., 111, D05S15, doi:10.1029/2004JD005646, 2006.

Pappalardo, G., Amodeo, A., Pandolfi, M., Wandinger, U., Ansmann, A., Bösenberg, J., Freudenthaler, V., Amiridis, V., De Tomasi, F., Frioud, M., Iarlori, M., Komguem, L., Papayannis, A., Rocadenbosch, F., and Wang, X.: Aerosol Lidar Intercomparison in the Framework of the EARLINET Project. 3. Raman Lidar Algorithm for Aerosol Extinction, Backscatter, and Lidar Ratio, Appl. Optics, 43, 5370-5385, 2004.

Pappalardo, G., Mona, L., D’Amico, G., Wandinger, U., Adam, M., Amodeo, A., Ansmann, A., Apituley, A., Alados Arboledas, L., Balis, D., Boselli, A., Bravo-Aranda, J. A., Chaikovsky, A., Comeron, A., Cuesta, J., De Tomasi, F., Freudenthaler, V., Gausa, M., Giannakaki, E., Giehl, H., Giunta, A., Grigorov, I., Groß, S., Haeffelin, M., Hiebsch, A., Iarlori, M., Lange, D., Linné, H., Madonna, F., Mattis, I., Mamouri, R.-E., McAuliffe, M. A. P., Mitev, V., Molero, F., Navas-Guzman, F., Nicolae, D., Papayannis, A., Perrone, M. R., Pietras, C., Pietruczuk, A., Pisani, G., Preißler, J., Pujadas, M., Rizi, V., Ruth, A. A., Schmidt, J., Schnell, F., Seifert, P., Serikov, I., Sicard, M., Simeonov, V., Spinelli, N., Stebel, K., Tesche, M., Trickl, T., Wang, X., Wagner, F., Wiegner, M., and Wilson, K. M.: Four-dimensional dis- tribution of the 2010 Eyjafjallajökull volcanic cloud over Europe observed by EARLINET, Atmos. Chem. Phys., 13, 4429-4450, doi:10.5194/acp-13-4429-2013, 2013.

Papayannis, A., Amiridis, V., Mona, L., Tsaknakis, G., Balis, D., Bösenberg, J., Chaikovski, A., De Tomasi, F., Grigorov, I., Mattis, I., Mitev, V., Müller, D., Nickovic, S., Pérez, C., Pietruczuk, A., Pisani, G., Ravetta, F., Rizi, V., Sicard, M., Trickl, T., Wiegner, M., Gerding, M., Mamouri, R. E., D'Amico, G., and Pappalardo, G.: Systematic lidar observations of aerosol optical properties during Saharan dust intrusions over Europe, in the frame of EARLINET (2000-2002): Statistical analysis and results, J. Geophys. Res., 113, D10204, doi:10.1029/2007JD009028, 2008.

Preißler, J., Wagner, F., Pereira, S. N., and Guerrero-Rascado, J. L.: Multi-instrumental observation of an exceptionally strong Saharan dust outbreak over Portugal, J. Geophys. Res., 116, D24204, doi:10.1029/2011JD016527, 2011.

Reichardt, J., Baumgart, R., and McGee, T. J.: Three-signal method for accurate measurements of depolarization ratio with lidar, Appl. Optics, 42, 4909-4913, 2003.

Sassen, K.: Polarization in Lidar, Lidar, edited by: Weitkam, C., Springer Press: New York, 19-42, 2005.

Sassen, K., Zhu, J., Webley, P., Dean, K., and Cobb, P.: Volcanic ash plume identification using polarization lidar: Augustine eruption, Alaska, Geophys. Res. Lett., 34, L08803, doi:10.1029/2006GL027237, 2007.

Satheesh, S. K. and Krishna, K.: Radiative effects of natural aerosols: A review, Atmos. Environ., 39, 2089-2110, 2005.

Shin, S., Müller, D., Kim, Y. J., Tatarov, B., Shin, D., Seifert, P., and Noh, Y. M.: The Retrieval of the Asian Dust Depolarization Ratio in Korea with the Correction of the PolarizationDependent Transmission, Asia-Pacific, J. Atmos. Sci., 49, 19-25, doi:10.1007/s13143-013-0003-4, 2013.

Sugimoto, N. and Lee, C. H.: Characteristics of dust aerosols inferred from lidar depolarization measurements at two wavelengths, Appl. Optics, 45, 7468-7474, 2006.

Talianu, C., Nicolae, D., Ciuciu, J., Ciobanu, M., and Babin, V.: Planetary boundary layer height detection from lidar measurements, Optoelectron. Adv. Mater., 8, 243-246, 2006.

Tesche, M., Ansmann, A., Muller, D., Althausen, D., Engelmann, R., Freudenthaler, V., and Groß, S.: Vertically resolved separation of dust and smoke over Cape Verde using multiwavelength Raman and polarization lidars during Saharan Mineral Dust Experiment 2008, J. Geophys. Res., 114, D13202, doi:10.1029/2009JD011862, 2009a.

Tesche, M., Ansmann, A., Muller, D., Althausen, D., Mattis, I., Heese, B., Freudenthaler, V., Wiegner, M., Esselborn, M., Pisani, G., and Knippertz, P.: Vertical profiling of Saharan dust with Raman lidars and airborne HSRL in southern Morocco during SAMUM, Tellus B, 61, 144-164, 2009b.

Tesche, M., Detlef, M., Gross, S., Ansmann, A., Althausen, D., Freudenthaler, V., Weinzierl, B., Veira, A., and Petzold, A.: Optical and microphysical properties of smoke over Cape Verde inferred from multi-wavelength lidar measurements, Tellus B, 63, 677-694, 2011.

Veselovskii, I., Kolgotin, A., Griaznov, V., Muller, D., Wandinger, U., and Whiteman, D. N.: Inversion with regularization for the retrieval of tropospheric aerosol parameters from multi-wavelength lidar sounding, Appl. Optics, 18, 3685-3699, 2002. 
Veselovskii, I., Dubovik, O., Kolgotin, A. Lapyonok, T., Di Girolamo, P., Summa, D., Whiteman, D. N., Mishchenko, M., and Tanre, D.: Application of randomly oriented spheroids for retrieval of dust particle parameters from multi-wavelength lidar measurements, J. Geophys. Res., 115, D21203, doi:10.1029/2010JD014139, 2010.
Wagner, J., Ansmann, A., Wandinger, U., Seifert, P., Schwarz, A., Tesche, M., Chaikovsky, A., and Dubovik, O.: Evaluation of the Lidar/Radiometer Inversion Code (LIRIC) to determine microphysical properties of volcanic and desert dust, Atmos. Meas. Tech., 6, 1707-1724, doi:10.5194/amt-6-1707-2013, 2013. 